DOI: 10.34015/2523-4552.2019.1.05

УдК 342.95

Кізь C. M., здобувач Харківського національного університету внутрішніх справ

\title{
НЕДОЛІКИ АДМІНІСТРАТИВНО-ПРАВОВОГО ЗАКОНОДАВСТВА, ЩО НЕГАТИВНО ПОЗНАЧАЮТЬСЯ НА ДІЯЛЬНОСТІ СПЕЦІАЛІЗОВАНОЇ АНТИКОРУПЦІЙНОЇ ПРОКУРАТУРИ
}

Автором акцентовано увагу на тому, що процес удосконалення організації та функціонування Спеціалізованої антикорупційної прокуратури неможливий без перегляду ряду норм адміністративного права, які визначають основні засади іï роботи. Насамперед, необхідно уніфікувати термінологію, яка застосовується в профільних нормативно-правових актах, переглянути адміністративно-деліктне законодавство щодо встановлення відповідальності прокурорів за порушення антикорупційного законодавства, а також забезпечити реалізацію принципу незалежності.

Ключові слова: Спеціалізована антикорупційна прокуратура; адміністративно-правове законодавство; публічне обвинувачення; державне обвинувачення; правопорушення, пов'язані з корупцією.

Автором акцентировано внимание на том, что процесс совершенствования организации и функционирования Специализированной антикоррупционной прокуратуры невозможен без пересмотра ряда норм административного права, которые определяют основные принципы ее работы. В частности, необходимо унифицировать терминологию, используемую в профильных нормативно-правовых актах, пересмотреть административно-деликтное законодательство в части установления ответственности прокуроров за нарушение антикоррупционного законодательства, а также обеспечить реализацию принципа независимости.

Ключевые слова: Специализированная антикоррупционная прокуратура; административно-правовое законодательство; публичное обвинение; государственное обвинение; правонарушения связанные с коррупцией.

Постановка проблеми. У сучасному світі складно уявити побудову та розвиток юридичних відносин без їх належної правової регуляції за допомогою законодавчо закріплених обов'язкових (до виконання та додержання) норм і правил пове- дінки для суб'єктів - учасників правовідносин. Право настільки успішно асимілювалося в майже в кожну сферу громадського життя та побуту, що стало певним всесвітнім стандартом, без якого подальша розбудова демократичного суспільства неможлива. 
Самі ж громадяни, не замислюючись, кожен день стають суб'єктами правових відносин один з одним або між ними та державою. Зазначене свідчить про чималу роль права в суспільстві, а відповідно і правових норм, які вже упродовж століть виступають регуляторами різноманітних відносин між множиною їх учасників.

Із розвитком правовідносин розвивалось і право, перші згодом були поділені на види, кожному 3 яких відповідала конкретна галузь права. Наприклад, приватні цивільно-правові відносини регулюються за допомогою норм цивільного законодавства, а публічні адміністративні правовідносини - за допомогою адміністративно-правових норм. Узагалі останні поміж інших видів правових норм мають унікальні особливості, які, насамперед, обумовлюються обов'язковою участю в них держави в особі їі органів. Разом із тим норми адміністративного права впорядковують сукупність відносин, що виникають у межах управлінської діяльності, та виступають засобом організації роботи державних інституцій, однією з яких є Спеціалізована антикорупційна прокуратура. Тобто безпосереднє вдосконалення її діяльності неможливе без оптимізації адміністративно-правових приписів, які в сукупності становлять частину національного адміністративноправового законодавства.

Аналіз останніх досліджень і публікацій. Місце і роль адміністративного права в регулюванні діяльності органів Спеціалізованої антикорупційної прокуратури визначено на підставі теоретичних здобутків таких учених, як В. В. Галунько, П. В. Діхтієвський, Р. В. Ігонін, З. Р. Кісіль, Р.-В. В. Кісіль, Т. О. Коломоєць,
В. К. Колпаков, О. В. Константий, Р. І. Корнута, О. В. Кузьменко, В. В. Середа, С. Г. Стеценко. Одночасно мета цієї наукової статті обумовлює необхідність з'ясування змісту основних законодавчих і підзаконних нормативно-правових актів, виявлення приписів, які містять неточності чи суперечать один одному. Унаслідок того, що Спеціалізована антикорупційна прокуратура - відносно новий суб'єкт боротьби 3 корупцією, комплексних досліджень щодо вдосконалення їі діяльності майже не провадилося, тому цей напрям наукових пошуків залишається актуальним, незважаючи на наявність окремих наукових робіт, присвячених здебільшого здійсненню прокурорами публічного обвинувачення (А. О. Гавенко, В. С. Остапець, С. О. Патюк, I. Ю. Шидловська, I. I. Шульга, М. Є. Шумило).

Постановка завдання. Мета статті полягає в аналізі норм низки чинних нормативно-правових актів, переважно тих, що містять приписи адміністративного законодавства, які регулюють діяльність органів Спеціалізованої антикорупційної прокуратури, 3 метою виявлення неточностей прогалин і недоліків, які негативно позначаються на організації діяльності вказаного антикорупційного органу.

Виклад основного матеріалу. Під адміністративним законодавством прийнято розуміти сукупність нормативно-правових актів, зведених у єдину систему, де знаходять своє зовнішнє вираження найбільш значущі норми адміністративного права [1, с. 10]. У свою чергу, нормативноправовий акт - це «письмовий документ компетентного суб'єкта владних повноважень, який містить формально обов'язкове правило поведінки 
загального характеру [2, с. 53] і приймається за чітко визначеною спеціальною процедурою, що в цілому надає йому юридичну силу (законодавчі та підзаконні акти правового характеру), яка визначає його місце в загальній системі національного законодавства. Таким чином, адміністративно-правове законодавство нерозривно пов'язане 3 поняттям «джерела адміністративного права», під яким розуміють «зовнішні форми встановлення і виразу загальнообов'язкових правил поведінки, які регулюють суспільні відносини, що виникають у сфері державного управління, акти правотворчості державних органів (законодавчих, виконавчих, судових, господарського управління), місцевих рад та їх виконкомів, а іноді громадських організацій (коли вони виконують функції виконавчої влади)» [3, c. 23]. Далі важливо встановити таку систему та її складові елементи, особливо зважаючи на те, що в сучасній доктрині адміністративного права підходи щодо їі розуміння відрізняються між собою. Так С. Г. Стеценко до системи джерел адміністративного права, тобто адміністративноправового законодавства, відносить закони, підзаконні нормативноправові акти та міжнародні договори, ратифіковані Верховною Радою України $[4$, с. 38]. В. К. Колпаков пропонує доповнити таку систему актами судових установ, тобто рішень, постанов, рідше - ухвал суду [5, с. 166]. Найбільш показовою в цьому разі, напевно, можна вважати розгалужену систему джерел адміністративного права, запропоновану авторами підручника «Адміністративне право України. Повний курс»: 1) законодавчі акти (Конституція України, закони та підзаконні нормативно-правові акти);
2) міжнародні джерела адміністративного права (міжнародні договори, юридичні акти Європейського Союзу, а також так зване «м'яке право»); 3) рішення судових органів, зокрема Європейського суду 3 прав людини, Конституційного Суду України, Верховного Суду України; 4) неформалізовані квазіджерела. Безпосередньо до неформалізованих джерел адміністративного права належить звичаї, традиції, норми моралі та правова доктрина: «за сучасного стану нормативного регулювання діяльності публічної адміністрації для неформалізованих джерел адміністративного права залишається доволі небагато місця, проте це не виключає можливості їх існування» [2, с. 68].

Організація та функціонування Спеціалізованої антикорупційної прокуратури в найзагальнішому розумінні являє собою сукупність суспільних відносин, які виникають 3 приводу вирішення управлінських та інших питань, спрямованих на забезпечення їі діяльності. Указані відносини виникають, розвиваються та припиняються на підставі відповідних нормативних положень переважно адміністративного законодавства. Це можна пояснити специфікою адміністративного права як публічно-правової галузі. Його норми призначені для врегулювання зв'язків, тобто правовідносин, де «однією стороною $є$ орган державної влади, орган місцевого самоврядування або суб'єкт делегованих повноважень, що діє з приводу і з метою реалізації публічних функцій і завдань, спрямованих на задоволення публічного інтересу» [6, с. 77].

Необхідно погодитися з рядом науковців (В. В. Середа, 3. Р. Кісіль і Р.-В. В. Кісіль) з приводу того, що 
«адміністративне право створює певний правовий режим для здійснення управлінських функцій, що $\epsilon$ найважливішою умовою впорядкованості сфери державного управління. Закріплення в юридичних нормах правил поведінки (яким чином слід діяти в конкретній ситуації, від чого слід утриматися, що робити категорично заборонено тощо) надає управлінським відносинам юридичного характеру, перетворює неправові відносини на формально-обумовлені» [7, c. 12]. За таких умов стають можливими реалізація управлінської діяльності, наділення відповідних посадових осіб повноваженнями, необхідними їм для виконання функціональних обов'язків, i, як наслідок, виконання завдань, поставлених перед державними інституціями, до яких належить і Спеціалізована антикорупційна прокуратура. Схожої думки притримується Р. В. Ігонін: «адміністративне право як одна 3 провідних галузей публічного права найбільш об'ємна за предметом правового регулювання. Це пояснюється тим, що адміністративне право $є$ управлінським правом, а його назва походить від латинського слова administrare, що означає управляти (керувати). Отже, очевидно, що його виникнення й існування зумовлено необхідністю правового забезпечення основної функції держави - управління» [8, c. 46].

Узагальнюючи наведене, зазначимо, що досліджувати питання вдосконалення діяльності Спеціалізованої антикорупційної прокуратури в Україні, насамперед, необхідно починати 3 адміністративно-правового законодавства, тому що саме воно є загальним правовим фундаментом існування та функціонування вказаного ор- гану державної влади. А його норми, що стосуються Спеціалізованої антикорупційної прокуратури, закріплюють порядок ії створення, повноваження, особливості діяльності; установлюють методи, способи та форми організації та управління окремими структурними підрозділами; забезпечують дотримання законності співробітниками; визначають напрями взаємодії 3 іншими державними та недержавними органами, громадянами, їх об'єднаннями. До того ж наведене демонструє важливість правових норм, зокрема адміністративних, від якості, актуальності та реалізації яких залежить ефективність роботи Спеціалізованої антикорупційної прокуратури. У такому разі важливо, щоб правові норми були максимально прозорі та зрозумілі як для посадових осіб, у тому числі фахівців у галузі права, так і для пересічних громадян. I навпаки - наявність мертвих, незрозумілих і непринципових норм значно знижує результати роботи органів, діяльність яких регулюється подібними правовими приписами.

Привертає увагу очевидна відмінність викладення функцій прокуратури, у тому числі і Спеціалізованої антикорупційної прокуратури, в Основному законі держави [9], провідному нормативно-правовому акті Законі України «Про прокуратуру» [10] та профільному підзаконному нормативному-правовому акті - Положенні про Спеціалізовану антикорупційну прокуратуру Генеральної прокуратури України, затвердженому наказом Генеральної прокуратури України від 12.04.2016 № 149 [11] (далі - Положення про САП), а також ототожнення в змісті останніх двох правових актів завдань і функцій. При цьому функції прокуратури, викладе- 
ні у ст. 131-1 Конституції України [9] та ст. 2 Закону України «Про прокуратуру» [10], за своєю змістовою сутністю тяжіють до завдань органів прокуратури, включаючи Спеціалізовану антикорупційну прокуратуру.

Під час аналізу приписів зазначених статей також звертає на себе увагу наявність термінологічних неточностей, а саме вживання понять «публічне обвинувачення» $\mathrm{i}$ «державне обвинувачення». Так, у пункті 1 частини першої статті 131-1 Конституції України вказано, що «в Україні діє прокуратура, яка здійснює: підтримання публічного обвинувачення в суді», а відповідно до пункту 1 частини першої статті 2 Закону України «Про прокуратуру» та пункту 3.4 розділу 3 Положення про САП [11] на прокуратуру покладається функція підтримання державного обвинувачення в суді. Останнє означає «процесуальну діяльність прокурора, що полягає у доведенні перед судом обвинувачення з метою забезпечення кримінальної відповідальності особи, яка вчинила кримінальне правопорушення» [12] (пункт 3 частини 1 статті 3 Кримінального процесуального кодексу України). Легалізоване визначення публічного обвинувачення в національній нормативно-правовій базі відсутнє, що буквально змушує звернутися до наукових розробок із окресленого питання. До речі, серед останніх теж простежуються певні відмінності. Зокрема, В. С. Остапець розглядає державне обвинувачення як окремий вид публічного, наділяючи останнє широким змістом, насамперед 3 огляду на коло суб'єктів його реалізації, де перше «здійснюється прокурором у різних формах з метою застосування кримінального закону до осіб, які скоїли злочин, і спрямоване на захист прав та свобод людини, громадянина, особистості, інтересів суспільства, держави та сприяння суду в забезпеченні законності у судовому процесі» [13, с. 117].

М. Є. Шумило під публічним обвинуваченням пропонує розуміти «офіційну постановку питання про винність особи у вчиненні злочину i можливу їі кримінальну відповідальність 3 метою захисту держави та суспільства від злочинних посягань» $[14$, c. 746]. Слід вказати, що таке визначення свідчить про відмінність публічного обвинувачення від державного з огляду на те, що перше, посуті, $є$ лише оприлюдненням думки щодо винності особи, i, як наслідок, її «обговорення», у той час коли державне обвинувачення - це не що інше як процедура, у межах якої доводиться вина особи. Схожий погляд сповідує I. І. Шульга: «поняття публічне обвинувачення є дещо ширшим за поняття державне обвинувачення. Адже виходячи зі змісту вкладеного в термін публічний, можемо констатувати, що прокурор у кримінальному провадженні виступає не тільки від імені держави, а і від імені всього суспільства (принаймні більшої його частини)» $[15$, с. 239$]$.

Разом 3 тим існують інші погляди. Наприклад, Ю. І. Шидловська та А. О. Говенко вживають терміни «державне обвинувачення» та «публічне обвинувачення» як синоніми, указуючи, що «підтримання прокурором державного обвинувачення в суді $\epsilon$ найбільш публічним виявом діяльності органів прокуратури, що потребує високого професіоналізму та самовідданості» [16, с. 359]. Це функція, яка найповніше забезпечує захист прав, свобод і законних інте- 
ресів людини від посягань. Заміну поняття «державне обвинувачення» на близьке, але більш змістовне «публічне обвинувачення» підтримує також С. О. Патюк [17].

Не занурюючись у дискусію 3 приводу сутності та відмінностей державного та публічного обвинувачення, слід вказати, що взагалі ми погоджуємось із тими вченими, які наділяють публічне обвинувачення ширшим змістом і наголошують на необхідності уніфікації обох понять, об'єднавши їх у єдиному терміні «публічне обвинувачення». Тому що саме останнє не тільки є сучасним поняттям, яке використовується для позначення такої функції прокуратури в зарубіжних державах, а й відповідає сутності правоохоронної реформи, заснованої на людиноцентричному підході, є узгодженим із рядом міжнародних документів і практикою Європейського суду з прав людини. Обвинувачення в такому випадку висувається не від імені держави, а в інтересах всього суспільства чи переважної його більшості задля охорони прав і свобод останнього.

Спеціалізована антикорупційна прокуратура України безумовно має особливий статус, оскільки наділена рядом повноважень спрямованих на протидію «невиліковній хворобі» корупції. Характер завдань, що ставляться перед працівниками цього органу, покладає на них подвійну відповідальність не тільки професійно та неупереджено здійснювати власну діяльність, а й бути взірцем для населення - органом, вільним від будь-яких корупційних проявів. У Кодексі професійної етики та поведінки прокурорів, затвердженому Всеукраїнською конференцією прокурорів 27.04.2017, закріплено осно- вні вимоги до професійної поведінки прокурорів, у тому числі тих, що обіймають посади в Спеціалізованій антикорупційній прокуратурі, серед яких - вимоги щодо недопущення корупції, а саме: «прокурор має суворо дотримуватись обмежень, передбачених антикорупційним законодавством, не допускати будь-яких проявів, які можуть створити враження корупційних, у тому числі: вступати у позаслужбові стосунки 3 метою використання службових повноважень або службового становища; неправомірно втручатися чи здійснювати у випадках чи порядку, не передбачених законодавством, вплив на службову діяльність іншого прокурора, службових, посадових осіб органів державної влади, органів місцевого самоврядування чи суддів. Прокурор, якому стала відома інформація про порушення вимог частини першої цієї статті іншим працівником прокуратури, зобов'язаний негайно повідомити про це відповідного керівника органу прокуратури» [18, стаття 19]. На нашу думку, подібні норми, які закріплюють підвищені вимоги до працівників органів, діяльність яких спрямована на протидію корупції, повинні кореспондуватись із підвищеною юридичною відповідальністю за правопорушення, пов'язані 3 корупцією, зокрема ті, що можуть бути вчинені особливим суб'єктом - прокурором Спеціалізованої антикорупційної прокуратури, у тому числі всупереч наведеним вимогам щодо професійної діяльності прокурорів. Крім того, за таких умов найбільш повно знаходять утілення такі принципи юридичної відповідальності, як доцільність і обгрунтованість. Перший у цій ситуації реалізується в 
частині персоніфікації заходів державного примусу та санкцій, які застосовуються до правопорушника, саме на підставі статусу та особливих характеристик останнього. Його реалізація означає визначення обставин, наявність яких може призвести до пом'якшення чи обтяження санкції в межах притягнення особи до юридичної відповідальності, а також кваліфікації їі протиправних діянь згідно з іншими нормами адміністративного права. Принцип обгрунтованості передбачає встановлення факту вчинення правопорушення, зокрема адміністративного, та притягнення винної особи до відповідальності.

Прокурори в процесі здійснення власної професійної діяльності повинні додержуватися низки регламентованих чинним законодавством вимог, у тому числі тих які знайшли відображення в Кодексі професійної етики та поведінки прокурорів, зокрема стосовно дотримання норм антикорупційного законодавства. Але в разі їх порушення вказану посадову особу можна притягнути лише до дисциплінарної відповідальності, що саме собою навряд чи доцільно, ураховуючи масштаби небезпеки та негативного впливу корупційних явищ і проявів. Навпаки, установлення за порушення прокурорами окремих правил, пов'язаних із недопущенням проявів корупції, саме адміністративної відповідальності, на нашу думку, є найбільш обгрунтованим, виходячи 3 юридичної природи власне адміністративного права та його управлінського характеру.

Водночас у правосвідомості переважної більшості населення явище корупції пов'язано виключно 3 да- ванням або отриманням хабара, але насправді охоплює ширший перелік дій. Тому з огляду на специфічну діяльність цього органу одною з основних засад його діяльності $є$ його незалежність як принцип, закріплений у чинному законодавстві, що сприяє забезпеченню реальних умов увільнення органів Спеціалізованої антикорупційної прокуратури від будьякого стороннього впливу як зовнішнього, так і внутрішнього характеру. Компетенція Спеціалізованої антикорупційної прокуратури поширюється на особливі категорії правопорушень, що обумовлено або суб'єктом такого правопорушення, або обсягом суспільної шкоди та небезпеки, що ним завдається. За таких умов питання щодо незалежності органів Спеціалізованої антикорупційної прокуратури набуває особливої актуальності в контексті вдосконалення механізму реалізації принципу незалежності. На сьогодні Спеціалізована антикорупційна прокуратура є підрозділом, що діє в складі Генеральної прокуратури України та підпорядковується керівнику останньої. Таким чином, Генеральний прокурор України може безпосередньо впливати на хід справ, які ведуться органами Спеціалізованої антикорупційної прокуратури, при цьому такий вплив може не завжди мати законний характер. У цьому разі виникає ризик, що орган, який був спеціально створений для боротьби 3 корупційними осередками, може стати об'єктом їх поширення. Звичайно, сторонній вплив на діяльність Спеціалізованої антикорупційної прокуратури може мати місце не тільки з боку керівництва Генеральної прокуратури, проте таке підпорядкування створює сприятливі 
умови для «корегування» рішень, які приймаються працівниками Спеціалізованої антикорупційної прокуратури у власних інтересах або в інтересах третіх осіб.

Беручи до уваги особливі завдання, що покладаються на Спеціалізовану антикорупційну прокуратуру, та специфічну сферу її функціонування - протидію корупції, яка є однією із нагальних проблем сучасності, що потребує якомога швидшого вирішення, зниження рівня корупції в державі, оскільки він фактично гальмує процес розвитку країни, проведення реформ і побудови сучасної європейської держави, та призводить до порушення прав, свобод і законних інтересів громадян. У свою чергу, утвердження принципу незалежності в діяльності органів прокуратури буде сприяти неупередженому виконанню функцій, які на неї покладаються. Маємо думку, що повнішому втіленню вказаного принципу може сприяти зміна підпорядкування органів Спеціалізованої антикорупційної прокуратури на кшталт Національної поліції України, яка в межах реформи правоохоронних органів була демілітаризована, а їі діяльність сьогодні «спрямовується та координується Кабінетом Міністрів України через Міністра внутрішніх справ України згідно із законом» [19]. Буквально це означає, що керівник Міністерства внутрішніх справ України суттєво не впливає на роботу органів поліції, а виконує лише адміністративну (управлінську) функцію, приймаючи рішення виключно з питань функціонування органів поліції, у той час коли завдання, напрями діяльності, межі компетенції визначає уряд.

Ураховуючи такий приклад, уважаємо за можливе запропонувати два шляхи надання автономії Спеціалізованій антикорупційній прокуратурі. Перший полягає в її виключенні зі складу Генеральної прокуратури України та наданні статусу самостійного органу державної влади зі спеціальним колом повноважень у сфері протидії корупції. Інший підхід $\epsilon$ менш кардинальним, оскільки Спеціалізована антикорупційна прокуратура може залишитись у складі Генеральної прокуратури України як відокремлений підрозділ останньої, але при цьому необхідно на законодавчому рівні визнати Генерального прокурора України лише посередником між вказаним органом і суб'єктом, який буде координувати та визначати пріоритетні напрями їі роботи, наприклад Президентом України. Адже саме Глава держави, всесторонньо опікуючись нею, повинен бути одною 3 центральних фігур протидії корупції, приймаючи відповідні рішення і здійснюючи різнопланові дії управлінського характеру в межах компетенції, визначеної законом.

Висновки. Усе зазначене дозволяє виробити основні положення щодо вдосконалення адміністративного законодавства, призначеного для врегулювання діяльності Спеціалізованої антикорупційної прокуратури, які, насамперед, стосуються необхідності: 1) приведення окремих нормативно-правових актів (Кримінального процесуального кодексу України, Закону України «Про прокуратуру», Положення про САП), які регулюються діяльність Спеціалізованої антикорупційної прокуратури, у частині уніфікації термінології, яка в них використовується, дасть змогу чіткіше зрозуміти функції та завдання органів прокуратури, у тому числі Спеціалізованої антикорупційної 
прокуратури, а також буде сприяти правильному визначенню їх ролі та місця в процесі реалізації правоохоронної функції держави; 2) установлення додаткової адміністративної відповідальності для прокурорів, зокрема прокурорів Спеціалізованої антикорупційної прокуратури, за вчинення адміністративних правопорушень, пов'язаних із корупцією та дотриманням вимог, закріплених у Кодексі професійної етики та пове- дінки прокурорів; 3) усестороннього забезпечення принципу незалежності. Одночасно Спеціалізована антикорупційна прокуратура $\epsilon$ відносно новим органом, у тому числі й у системі суб'єктів боротьби з корупцією, що обумовлює подальшу необхідність вивчення процесів її спільної діяльності 3 іншими суб'єктами реалізації державної антикорупційної політики в Україні, зокрема в частині їх удосконалення.

\section{Список використаних джерел}

1. Словник базової термінології з адміністративного права : навч. посіб. / за заг. ред. Т. О. Коломоєць. Київ : Істина, 2010. 234 с.

2. Адміністративне право України. Повний курс : підручник / В. В. Галунько, П. В. Діхтієвський, О. В. Кузьменко, С. Г. Стеценко [та ін.]. Херсон : «ОЛДІ-ПЛЮС», 2018. $446 \mathrm{c}$.

3. Константий О.В.Джерела адміністративного права України: монографія. Київ: Українське агентство інформації та друку «Рада», 2005. 345 с.

4. Стеценко С. Г. Адміністративне право України. Київ : Атіка, 2007. 624 с.

5. Колпаков В.К., Коломоєць Т. О. Вступ до навчального курсу «Адміністративне право України». Київ : «Ін Юре», 2014. 240 с.

6. Корнута Р. I. Визначення поняття публічного права в праві України. Український часопис міжнародного права. 2003. № 2. С. 77-88.

7. Середа В. В., Кісіль 3. Р., Кісіль Р. В.-В. Адміністративне право : навч. посібник. Львів : ДУВС, 2014. 520 с.

8. Ігонін Р. В. До питання предмета адміністративного права. Вісник Академії митної служби України. Серія: Право. 2010. № 1. С. 46-51.

9. Конституція України від 28.06.1996 № 254к/96-ВР. Відомості Верховної Ради України. 1996. № 30. Ст. 141.

10.Про прокуратуру: закон України від 14.10.2014. № 1697-VII. Відомості Верховної Ради України. 2015. № 2-3. Ст. 12.

11.Положення про Спеціалізовану антикорупційну прокуратуру Генеральної прокуратури України: наказ Генеральної прокуратури України від 12.04.2016 № 149 // База даних «Законодавство України» / Верховна Рада України. URL:https://zakon.rada.gov.ua/rada/show/v0149900-16 (дата звернення 20.05.2019).

12.Кримінальний процесуальний кодекс України від 13.04.2012. № 4651-VI. Відомості Верховної Ради України. 2013. № 9-10, № 11-12, № 13. Ст. 88.

13.0стапець В. С. Співвідношення понять «державне обвинувачення» та «кримінальне переслідування» у проекті кримінального процесуального кодексу України. Вісник національної академії прокуратури України. 2009. № 2. С. 144-119.

14. Шумило М. Є. Публічне обвинувачення. Великий енциклопедичний юридичний словник / за заг. ред. Ю. С. Шемшученка. Київ : Юридична думка, 2007. 990 с.

15.Шульга I.I. Окремі аспекти підтримання прокурором публічного обвинувачення. Юридичний науковий електронний журнал. 2016. № 2. C. 238-240. URL: http://lsej.org.ua/6_2016/66.pdf (дата звернення 20.05.2019). 
16. Шидловська I. Ю., Гавенко А. О. Підтримка державного обвинувачення прокурором в суді. Грані права: ХХІ століття : зб. матеріалів Всеукраїнської науковопрактичної конференції (м. Одеса, 19 травня 2018 року): у 2 т. Одеса : Видавничий дім «Гельветика», 2018. Т. 2. С. 359-362.

17.Патюк С. О. Нормативна невизначеність співвідношення категорій «державне» та «публічне» обвинувачення як підстава для зловживання правом у кримінальному провадженні. Економіко-правова парадигма. 2016. № 2. C. 1-14. URL: https://studlib.org.ua/index.php/eprs/article/view/73/69 (дата звернення 20.05.2019).

18. Кодекс професійної етики та поведінки прокурорів : Кодекс; Генеральна прокуратура України від 27.04.2017 // База даних «Законодавство України» / Верховна Рада України. URL: https://zakon.rada.gov.ua/go/n0001900-17 (дата звернення 20.05.2019).

19. Про Національну поліцію: закон України від 02.07.2015 № 580-VIII. Biдомості Верховної Ради України. 2015. № 40-41. Ст. 379.

\section{References}

1. Kolomoyec, T. O. (Zag. red.). (2010). Slovnik bazovoyi terminologiyi $z$ administrativnogo prava: navch. posib. Kiyiv: Istina [in Ukrainian].

2. Galunko, V. V., Dihtiyevskij, P. V., Kuzmenko, O. V., Stecenko, S. G. (2018). Administrativne pravo Ukrayini. Povnij kurs: pidruchnik. Herson: «OLDI-PLYuS» [in Ukrainian].

3. Konstantij, O.V. (2005). Dzherela administrativnogo prava Ukrayini. Kiyiv: Ukrayinske agentstvo informaciyi ta druku «Rada» [in Ukrainian].

4. Stecenko, S. G. (2007). Administrativne pravo Ukrayini. Kiyiv: Atika, 2007 [in Ukrainian].

5. Kolpakov, V. K., Kolomoyec, T. O. (2014). Vstup do navchalnogo kursu «Administrativne pravo Ukrayini». Kiyiv: In Yure [in Ukrainian].

6. Kornuta, R. I. (2003). Viznachennya ponyattya publichnogo prava v pravi Ukrayini. Ukrayinskij chasopis mizhnarodnogo prava. 2, 77-88 [in Ukrainian].

7. Sereda, V. V., Kisil, Z. R., Kisil, R. V.-V. (2014). Administrativne pravo: navch. posibnik. Lviv: DUVS [in Ukrainian].

8. Igonin, R. V. (2010). Do pitannya predmeta administrativnogo prava. Visnik Akademiyi mitnoyi sluzhbi Ukrayini. Seriya: Pravo. 1, 46-51 [in Ukrainian].

9. Konstituciya Ukrayini vid 28.06.1996. N 254k/96-VR. Vidomosti Verhovnoyi Radi Ukrayini. 1996. 30. St. 141 [in Ukrainian].

10. Pro prokuraturu: zakon Ukrayini vid 14.10.2014 N 1697-VII. Vidomosti Verhovnoyi Radi Ukrayini. 2015. 2-3. St. 12 [in Ukrainian].

11.Polozhennya pro Specializovanu antikorupcijnu prokuraturu Generalnoyi prokuraturi Ukrayini: nakaz Generalnoyi prokuraturi Ukrayini vid 12.04.2016. N 149 / Baza danih «Zakonodavstvo Ukrayini» / Verhovna Rada Ukrayini. URL:https://zakon.rada.gov.ua/ rada/show/v0149900-16 (data zvernennya 20.05.2019) [in Ukrainian].

12. Kriminalnij procesualnij kodeks Ukrayini vid 13.04.2012. N 4651-VI. Vidomosti Verhovnoyi Radi Ukrayini. 2013. N 9-10, 11-12, 13. St. 88 [in Ukrainian].

13. Ostapec, V.S. (2009). Spivvidnoshennya ponyat «derzhavne obvinuvachennya» ta «kriminalne peresliduvannya» u proekti kriminalnogo procesualnogo kodeksu Ukrayini. Visnik nacionalnoyi akademiyi prokuraturi Ukrayini. 2, 144-119 [in Ukrainian].

14.Shumilo, M. Ye. (2007). Publichne obvinuvachennya. Velikij enciklopedichnij yuridichnij slovnik / za zag. red. Yu. S. Shemshuchenka. Kiyiv: Yuridichna dumka [in Ukrainian].

15. Shulga, I. I. (2016). Okremi aspekti pidtrimannya prokurorom publichnogo obvinuvachennya. Yuridichnij naukovij elektronnij zhurnal. 2, 238-240. URL: http://lsej.org.ua/6_2016/66.pdf (data zvernennya 20.05.2019) [in Ukrainian].

16. Shidlovska, I. Yu., Gavenko, A. O. (2018). Pidtrimka derzhavnogo obvinuvachennya prokurorom v sudi. Grani prava: XXI stolittya : zb. materialiv Vseukrayinskoyi naukovo- 
praktichnoyi konferenciyi (m. Odesa, 19 travnya 2018 roku): u 2 t. Odesa : Gelvetika. 2, 359362 [in Ukrainian].

17. Patyuk, S. O. (2016). Normativna neviznachenist spivvidnoshennya kategorij «derzhavne» ta «publichne» obvinuvachennya yak pidstava dlya zlovzhivannya pravom $\mathrm{u}$ kriminalnomu provadzhenni. Ekonomiko-pravova paradigma. 2, 1-14. URL: https://studlib.org.ua/index.php/eprs/article/view/73/69 (data zvernennya 20.05.2019) [in Ukrainian].

18. Kodeks profesijnoyi etiki ta povedinki prokuroriv: Kodeks; Generalna prokuratura Ukrayini vid 27.04.2017 / Baza danih «Zakonodavstvo Ukrayini» / Verhovna Rada Ukrayini. URL: https://zakon.rada.gov.ua/go/n0001900-17 (data zvernennya 20.05.2019) [in Ukrainian].

19. Pro Nacionalnu policiyu: zakon Ukrayini vid 02.07.2015 № 580-VIII. Vidomosti Verhovnoyi Radi Ukrayini. 2015. № 40-41. St. 379 [in Ukrainian].

\section{S. Kiz, Postgraduate student of the Kharkiv National University of Internal Affairs}

\section{Gaps of the administrative legislation, which negatively influence the activities of the specialized Anti-Corruption Prosecutor's Office}

The author focuses on the fact that the process of improving the organization and functioning of the Specialized Anti-Corruption Prosecutor's Office is impossible without revision of a number of norms of administrative law, which determine the basic principles of its work, in particular, it is necessary: unification of the terminology used in specialized normative acts; review the administrative and tort law in relation to establishing the responsibility of prosecutors for violating the anti-corruption legislation, and to ensure the implementation of the principle of independence.

The main provisions concerning the improvement of the administrative law, determined for the settlement of activities: 1) the bringing of certain normative legal acts of Ukraine; The General Prosecutor's Office of Ukraine dated April 12, 2016 No. 149) regulates the activities of the Specialized Anti-Corruption Authority in terms of the unification of terminology, which should be able to understand clearly the functions and tasks of the public prosecutor's office, including the Specialized Anti-Corruption Prosecutor's Office, and will help to correctly determine their role and places in the process of law enforcement functions of the state;

2) establishing additional administrative liability for prosecutors, as well as increasing the level of anti-corruption capacity of administrative law enforcement agencies with corruption policy, with the requirements set forth in the code of professional ethics and behavior of prosecutors approved by the All-Ukrainian Conference on April 27, 2017; 3) comprehensive assurance of the principle of independence. At the same time, the Specialized Anti-Corruption Prosecutor's Office is a relatively new body that performs the system of anti-corruption actors, which makes it necessary to study the processes of its joint activity with the subjects of the implementation of the state anti-corruption policy in Ukraine.

Keywords: specialized anti-corruption prosecutor's office; administrative law; prosecutor's office; prosecutor's office; corruption-related offenses.

Надійшла до редакції 20.05.2019 